\title{
Change Detection: Estimating the Footprint of the Kribi Agro-Industrial and Urban Port Complex (Cameroon) from Landsat Imagery
}

\author{
Jean Megope Foonde \\ Department of Geography, Northern Illinois University, DeKalb, USA \\ Email: jpmefoo@gmail.com
}

How to cite this paper: Megope Foonde, J. (2018) Change Detection: Estimating the Footprint of the Kribi Agro-Industrial and Urban Port Complex (Cameroon) from Landsat Imagery. Open Access Library Journal, 5: e4550.

https://doi.org/10.4236/oalib.1104550

Received: March 28, 2018

Accepted: May 12, 2018

Published: May 15, 2018

Copyright (c) 2018 by author and Open Access Library Inc.

This work is licensed under the Creative Commons Attribution International License (CC BY 4.0).

http://creativecommons.org/licenses/by/4.0/

\section{Open Access}

\begin{abstract}
In the coastal South region of Cameroon, 26.000 ha of land once covered by forest is doomed by the development of a significant infrastructure: the Kribi Agro-Industrial and Urban Port Complex. Important earthwork was undertaken to set-up this "structuring project" which is presented as the ultimate propeller for the industrialization of the entire Central Africa region. This paper is the first of a series aiming to use pixel-based digital image differencing to determine the footprint of the Kribi Agro-Industrial and Urban Port Complex at its present stage of development. Hopefully it triggers sound decisions and awareness on the fate of this biome, part of the Congo Rainforest.
\end{abstract}

\section{Subject Areas}

Environmental Sciences

\section{Keywords}

Bi-Temporal Assessment, Change Detection, Land Cover, Landsat, Remote Sensing

\section{Introduction}

Building new harbors is a trending in Africa. Mostly financed and built by China as a part of the implementation of its 21st Century Maritime Silk Road strategy also referred to as the Belt and Road [1], these new infrastructures all ambition to become regional hubs. Are cited El Hamdania (Algeria), Doraleh (Djibouti), Bagamoyo (Tanzania), Lamu (Kenya), Maputo (Mozambique), N’Diago (Mauritania), Boké-Dapilon (Guinea), Lekki (Nigeria), Owendo (Gabon) and last, Kribi (Cameroon) which is the subject of this paper. As the intent and nature of 
the Kribi multi-layered project are still being widely debated, little emphasis had been made on the environmental footprint of this endeavor. That is precisely the focus of this paper.

Since 2010, in the Coastal South region of Cameroon, the land west of the Lobé River (once covered by a very dense and diverse tropical rainforest) has been dedicated to the development of a large coastal agro-industrial and urban port complex also known as the Kribi Deep-Water Harbor, herein KDWH [2]. Long before its implementation, disagreements on the prioritization [3] [4] and the viability of this project were voiced, its sustainability questioned, the environmental damages and their adverse effects on the indigenous communities raised. After these concerns were presumably dealt with or swept aside, the fate of this ecosystem was sealed. On December 27th, 2010, earthworks started resulting in the first 60 ha of land been deforested for the phase 1 of the KDWH.

This project needs to be understood in relation to a specific legal, political and economic environment where no discussion on the proto-biome is deemed necessary, the capture of alterations neglected, progressions or regressions not recorded, withhold or lack of quantitative and reliable information prevalent, infringements and unaccountability recurrent, the reconciliation of sustainability with economic growth not well understood or valued [5], drifts not decried. This paper aims to use remote sensing capabilities and GIS spatial analysis functionalities to accurately assess damages and the ecological footprint of this project during its execution for a better environmental management of this ecosystem.

\section{The Kribi Agro-Industrial Port and Urban Complex Project}

The area covered by this study is in the Kribi I subdivision, Ocean division of the South region of Cameroon (Figure 1: location of the KDWH in Cameroun). It slightly encompasses the concession of the KDWH project. With a width of 10.5 $\mathrm{km}$ and a length of $23 \mathrm{~km}$, the Area of Interest (AOI) determined here is broadly 24,786 hectares comprised of 17,084 hectares of land and 7746 hectares of ocean. It stretches between latitudes $2^{\circ} 37^{\prime} 31^{\prime \prime}$ and $2^{\circ} 49^{\prime} 57^{\prime \prime}$ North, and the longitudes $9^{\circ} 50^{\prime} 14^{\prime \prime}$ and $9^{\circ} 56^{\prime} 2 "$ East. The major physical features here are the Lobé River in the North East and the Atlantic Ocean in the West. This area is a coastal plateau, with altitude ranging from 0 to $286 \mathrm{~m}(300 \mathrm{~m})$ is soaked by an equatorial climate characterized by a mean annual temperature of $26.8^{\circ} \mathrm{C}$ and an annual precipitation of $2817 \mathrm{~mm}$ distributed in four seasons: a major dry season from November to March, a minor rainy season from March to May, a minor dry season from June to Mid-august and a major wet season from Mid-august to November. Its original flora was a moist evergreen coastal forest where noticeable dominant species were: Lophira alata (Azobe), Sacoglottis gabonensis (Ozouga), Cynometra hankei, Strombosiopsis tetrandra, Coula edulis [6] (Letouzey 1986). Before 2010, this dense forest was longitudinally crossed by the Kribi-Campo oceanshore road (N7) alongside which were the following villages: Grand Batanga II, 


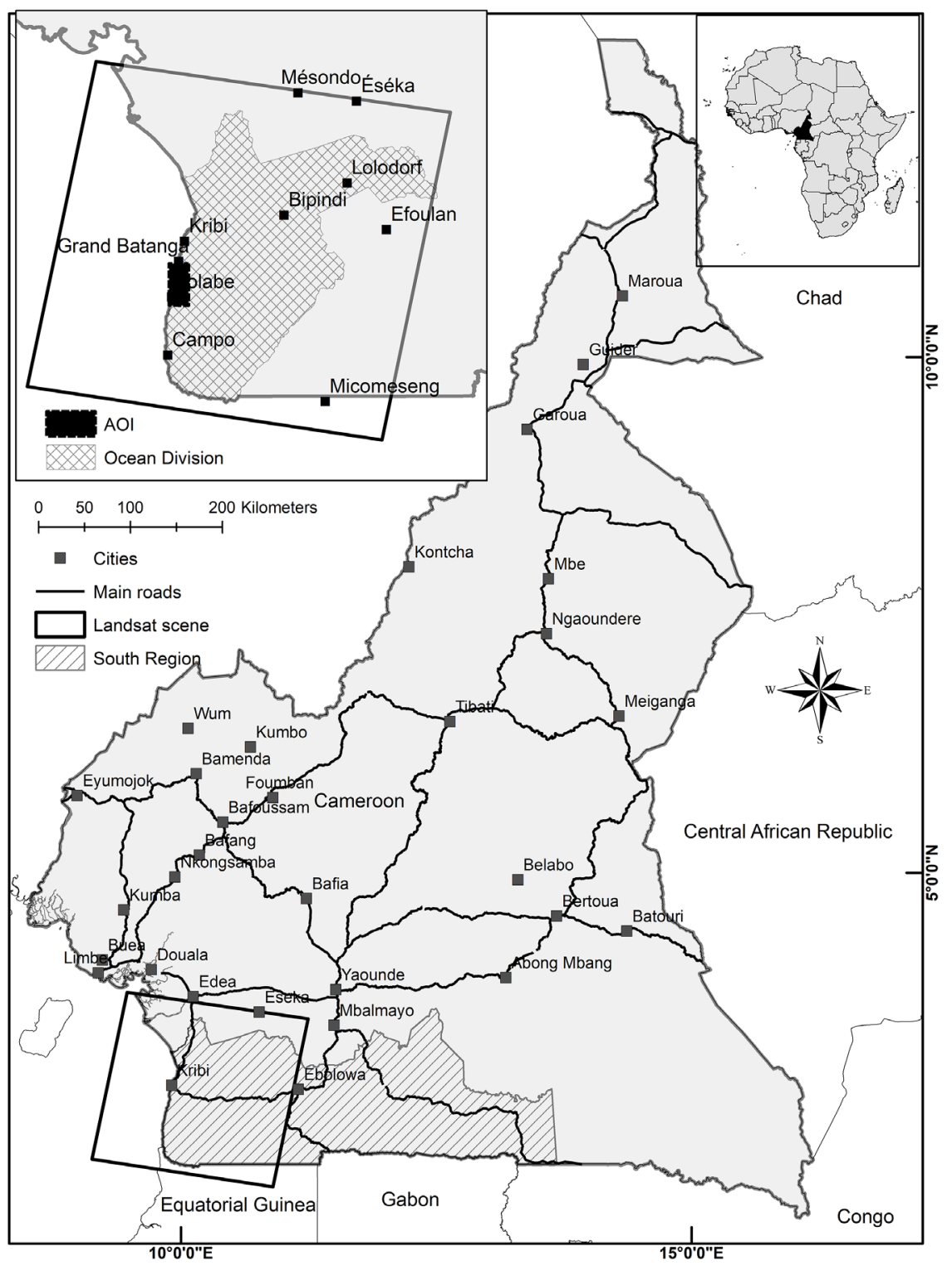

Figure 1. Location of the KDWH in Cameroun.

Eboundja I. Eboundja II, Nlende Dibe, Boussibelika, Mboro, Lolabe. Lohendje and, few Pygmies encampments.

Taking advantage of the Atlantic Ocean conditions and depth of $-20 \mathrm{~m}$ (66 $\mathrm{ft}$.) at less than a hundred meters from the coastline in this area [7] [8], amidst some controversies, the government of Cameroon choose to boost the economic growth and foster the industrialization of the whole central Africa hinterland by building a deep seaport complex centered on the seaside village of Mboro [9]. The KDWH is located approximately 30 kilometers south of the coastal town of Kribi, 200 kilometers south of Douala, the oldest and busiest harbor in Cameroon. The 25 kilometers in length industrial port complex at its completion by 2035 will be made of four main parts: a deep-water port with 20 wharfs which will be able to accommodate ships with more than $25 \mathrm{~m}$ draft, a zone for indus- 
trial and logistic activities (been built), a multimodal transport corridor named "backbone" (started), a not yet built new city of 100,000 inhabitants [10]. For the setting of all these infrastructures, huge excavations and other earthworks have taken place, resulting in the destruction of large portion of this land with a noticeable footprint.

\section{Cameroon's Land Cover Change Related Works}

Change detection consists of identifying land cover changes by observing a geographic area over a period. Land cover refers to the physical and biological cover over the surface land, including water, vegetation, bare soils and or artificial structures [11].

With the increased awareness of the earth's biosphere degradation, assessing the impact and footprint of human activities via satellite imagery has become a common practice since the seventies. Deforestation is a growing environmental problem in Cameroon [12] [13]. Since its forest is part of the Congo Rainforest (the second largest continuous tropical forest in the world), this ecosystem is subject of peculiar attention. That explains why organizations such as the Food and Agriculture Organization of the United Nations (FAO), United Nations Environment Programme (UNEP), Global Forest Initiative, The Global Forest Watch (World Resources Institute), World Wide Fund for Nature (WWF) and The Congo Basin Initiative use satellite imagery to monitor this biome, provide early warning, pinpoint onsets and hotspots, depict degradation trends and patterns [14] [15] [16] [17]. Also, in accordance with these global concerns, numerous studies using satellite imagery have been conducted to check the wellbeing of some of Cameroon's ecosystem [18]-[25]. Beside these, there is the often-cited Interactive Forestry Atlas of Cameroon [26]. Although these studies look numerous, they all tend to be generic and scale-dependent. They treat the southern Cameroon's forest broadly, and rarely focus on specific target.

This essay is based on the goals and methods of The Interactive Map of Hansen et al. [27] which using satellites imagery and based on canopy reflectance had successfully mapped forest loss and gain from 2001 to 2015 in our AOI, year by year, for the established period. It differs from the cited work which failed to capture the important change that had occurred on the ocean surface. The singularity of the Kribi deep-water harbor project is that it implies forest change and ocean change thus land cover change. This article is, therefore, the first of his kind to be conducted on this specific hotspot and, on this subject in Cameroon.

\section{Data Sources}

Remote sensing images have become the most efficient way of assessing land cover change. The main data source for this paper is Landsat images from NASA-USGS. Due to its free online availability and large historical archive, Landsat data offer a unique series of temporal observations of the Earth's surface 
and its modification over time [28]. Its moderate or medium spatial resolution $(30 \mathrm{~m})$ make it particularly suitable for pixel-by-pixel change detection analysis and, thus, for the mapping and monitoring of land cover as well as land surface biophysical and geophysical properties [29].

For accurate change detection evaluation, it is recommended to use images from the same sensor. It helps avoid that artefacts caused by different technical characteristics be interpreted as changes. The Kribi deep-water Harbor construction started in 2012 before Landsat 8 entered in service (2013). That accounts for the choice of the bi-temporal Landsat 7 ETM images used in this work. The first one, a January $5^{\text {th }}$, 2007 (Figure 2: Image A Landsat images in false Natural Color of the Kribi area) and the second image a December 29th, 2015 (Figure 3: Image B Landsat images in false Natural Color of the Kribi area), all downloaded from the USGS/EROS database. Although is two-year-old, the 2015 image still depicts the current ground reality because for several reasons, very little has been done since it was taken. The oldest image (2007) serves as the reference in this pixel-based comparison. It should be noted that the Landsat 7 ETM is an 8-bit images consisting of 7 spectral bands with a spatial resolution of 30 meters, covering an approximate scene size of $170 \mathrm{~km}$ north-south by $183 \mathrm{~km}$ east-west (106 $\mathrm{mi}$ by $114 \mathrm{mi}$ ). Because of the SLC (Scan Line Corrector) failure in 2003 , both images had to be destriped.

For the same reason, it is recommended to use cloud free images and that bi-temporal images be of near anniversary dates so that seasonal variation in

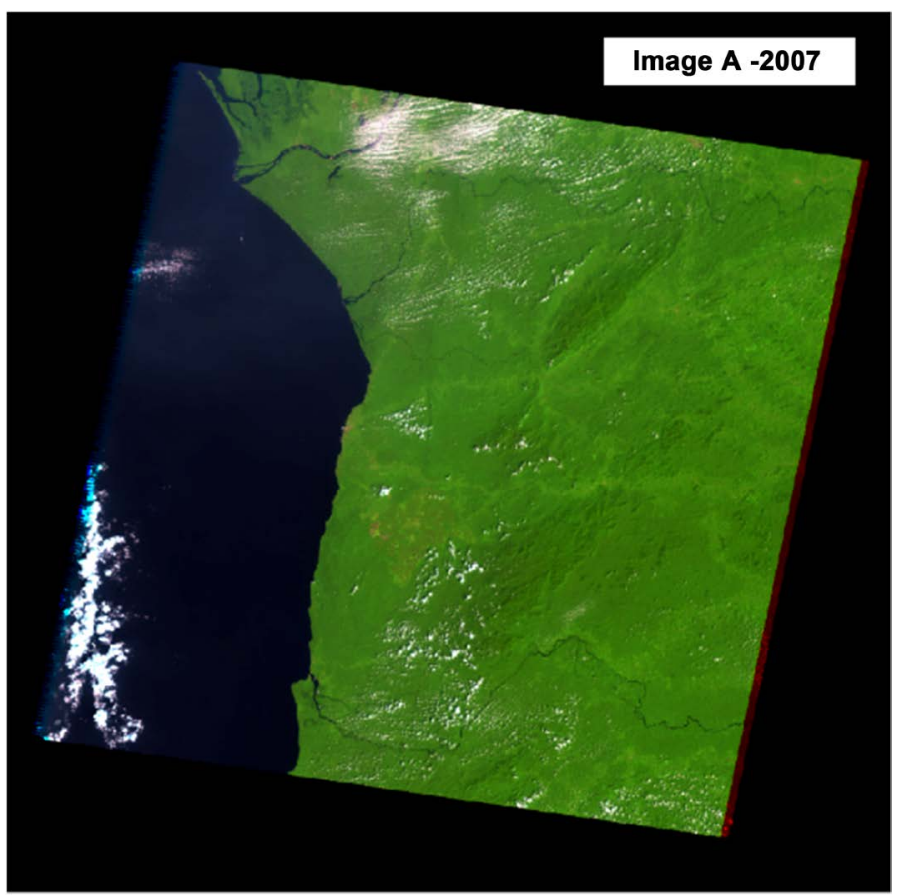

Figure 2. Image A-Landsat images in false Natural Color of the Kribi area Landsat 7 ETM-January 5, 2007. Image ID: LE07_L1TP_186058_20070105. Source: [U.S. Geological Survey (USGS) Earth Resources Observation and Science (EROS) Center]. 


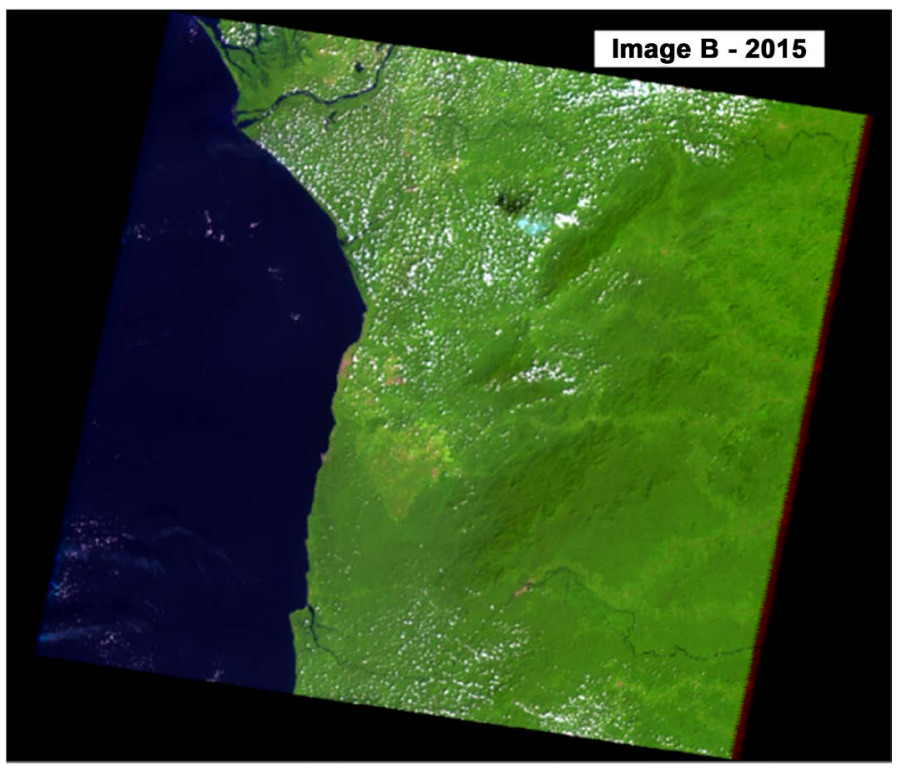

Figure 3. Image B Landsat images in false Natural Color of the Kribi area. Landsat 7 ETM-December 29, 2015. Image ID: LE07_L1TP_186058_20151229. Source: [U.S. Geological Survey (USGS) Earth Resources Observation and Science (EROS) Center].

phenological character of the vegetation under observation is kept at minimum. With respect to this recommendation, both images were taken during the major dry season (November-March), at a time when the land cloud cover was $4 \%$ for the 2007, 3\% for the 2015 and our AOI almost cloud free. Finally, the images chosen were already georeferenced and orthorectified with the UTM Zone 32N Coordinate on the WGS 84 reference system. However, even with these precautions minor inconsistencies between images are not excluded [30].

\section{Processing of Images for Change Detection}

There are four sequential objectives to Change detection: detecting if a change has occurred, identifying the nature of change, measuring the aerial extent of change, and assessing the spatial pattern of change [31]. The choice of the change detection methodologies and techniques that can be used to achieve these objectives depends on viewpoints since each of them has merits and problems. Considering the unit of image analysis, there are two groups of change detection methods: the traditional pixel-based Change detection (PBCD) and the object-based change detection (OBCD). To meet the main objective of this study which is to determine the foot print of the KDWH by mean of land cover change detection, I chose the pixel-based method. It entails different procedures and techniques which were iteratively ran through ERDAS Imagine 2016.

- Image stacking:

Raster $>>$ Spectral >> Layer Stack...

This operation consists in combining band layer (.TIFF) to produce a composite image (.img) that eliminates unwanted content or noise. This operation 
helps enhance images quality.

- Subset the Landsat image:

Raster $>>$ Subset\& Chip $>>$ AOI...

This process consisted of extracting the study area or Area of interest (AOI) from the whole scene (Figure 4: The Area of Interest in the scene).

- Image coregistration:

Raster $>>$ Geometric Tools $>>$ Coregister Image Pair...

This operation is key for comparison. It was performed to guarantee that a pixel in the comparing image corresponds to the same ground area in the reference image (Figure 5: 2007 and 2015 linkview of the coregistered and haze free subset images of the AOI).

- Radiometric normalization (Haze reduction):

Raster $>>$ Radiometric $>>$ Haze reduction...

Made up of atmospheric aerosols and molecules that scatter and absorb solar radiation, haze modifies the spectral signature of land classes and thus reduces classification accuracy. The technique used here is based on the Tasseled Cap (KT) transformation algorithm. The result shows an increase in the accuracy of the data statistically and visually.

- Classification of land cover:

There are numerous algorithms to classify an image. For the purposes of this study the k-means clustering unsupervised classification algorithm was used leading to the creation of 4 classes: Water (ocean and river), Clearings, Undisturbed Forest, Barren lands (roads, concrete...).

- Accuracy assessment:

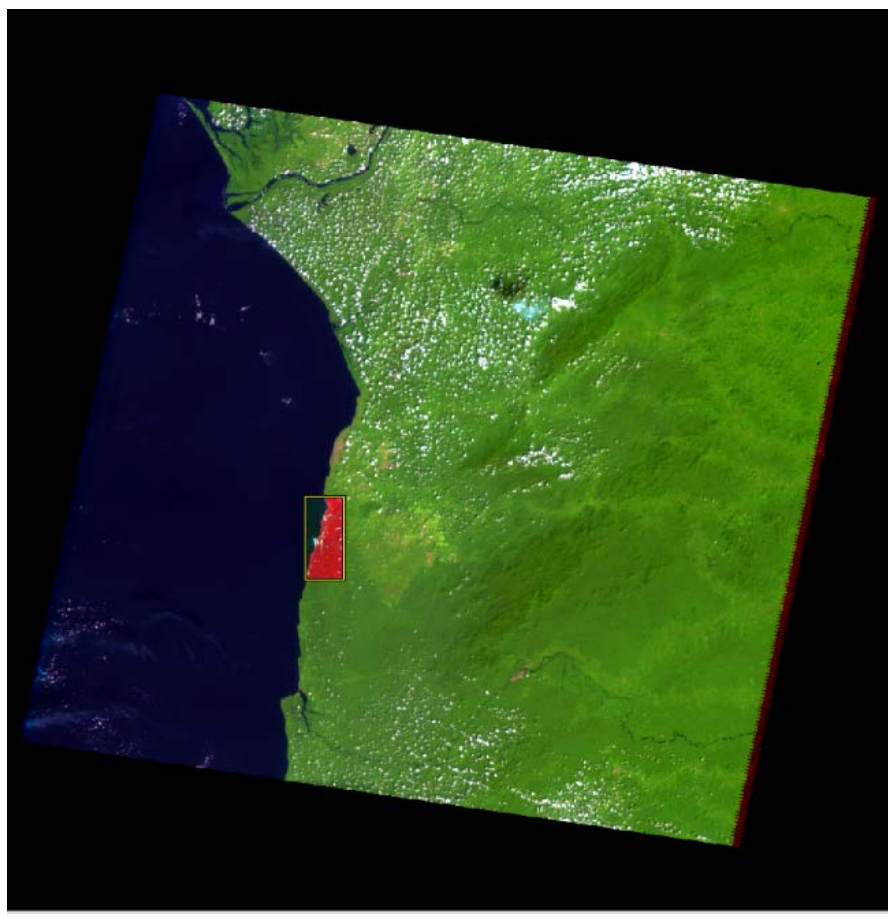

Figure 4. The Area of Interest in the scene. 


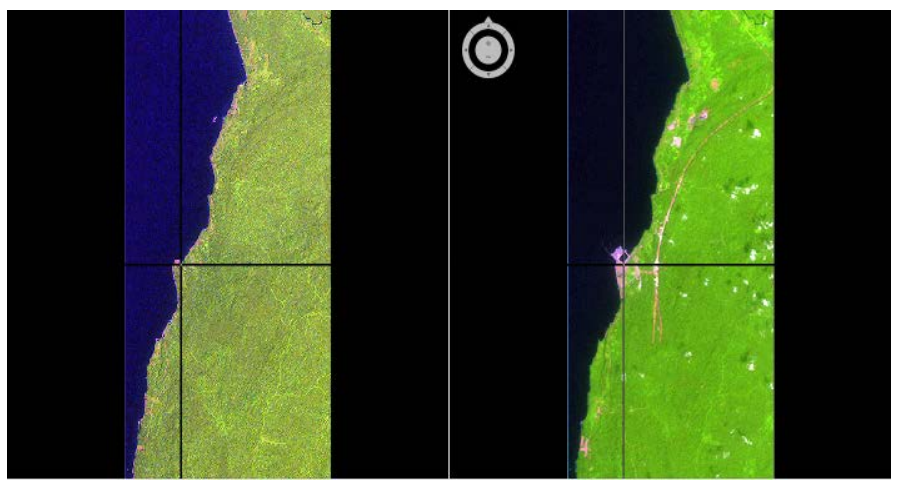

Figure 5. 2007 and 2015 linkview of the coregistered and haze free subset images of the AOI.

Raster $>>$ Supervised $>>$ Accuracy assessment $>>$ File $>>$ Create random point $>>$ select classes $>>$ report

The Landsat subset image was used as a surrogate for ground data to confirm the classification. With 0.0 Error Matrix, 100.00\% Overall Classification Accuracy and 1.0000 Overall Kappa Statistics the 2007 and 2015 classification were deemed good.

- Change detection by comparison (Image differencing):

Image Differencing is the most common methods used for change detection. It is a statistics-oriented change detection technique which focuses mainly on the spectral values. With this technique, images of the same area obtained from times $t 1$ or "as before" (image of 2007) and $t 2$ or "as after" (image of 2015) are subtracted pixelwise. Such change of detection model is based on neighborhood correlation image analysis made possible through the ERDAS Imagine software. This method only provides change/non-change information. The threshold choice is highly subjective and scene-dependent for binary segmentation. A lower threshold proved efficient in capturing minimal change whereas a higher threshold highlights critical damage. Taking in account that remote-sensing-based detection of forest degradation is difficult and subtle degradation signals not being easy to detect, many studies focused on canopy change uses a lower threshold of $5 \%$ to $20 \%$ [32]. Although trace of the damage may be quickly lost over time due to fast re-vegetation which can be as much as $10 \%$ per year, in order to capture the footprint of the $\mathrm{KDWH}$, a threshold was established at $35 \%$. The selection of this threshold to differentiate change from no-change areas result from an interactive or manual trial-and-error procedure. This threshold allowed the capture of the area directly damaged by the KDWH construction regardless of vegetation regeneration and of the time difference between the images. The choice of a suitable threshold is critical to identify the transformed areas. Despite some disadvantages, this procedure lead to a satisfactory outcome (Figure 6: land cover change in the kribi Deep Water harbor area between 2007 and 2015).

- Delineation of the footprint: 


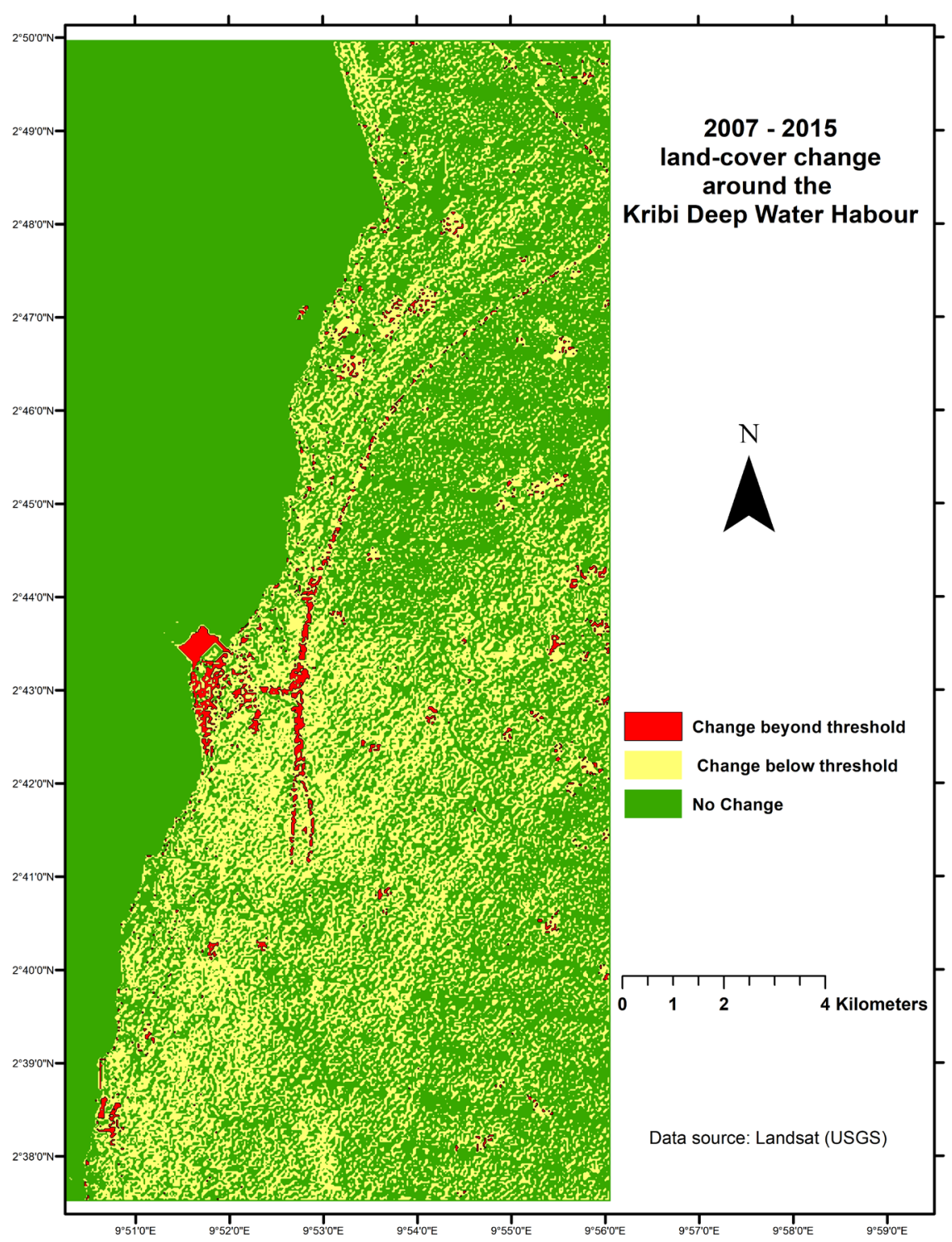

Figure 6. Land cover change in the kribi Deep Water harbor area between 2007 and 2015.

for the extraction of the surfaces that have changed during the construction of the Kribi deep water Harbor, the highlight raster classes were converted into shapefile.

\section{- Artefacts removal:}

The artefacts removal process was conducted manually to removed return of change caused by the presence of some residuals clouds

- Ground verification:

In lieu of ground verification, higher resolution imagery from Google Earth was used as an alternative.

\section{The Footprint of the Kribi Deep Water Habour}

Using the spatial statistic tools, between 2007 and 2015, on the 24,786 hectares of the AOI, reflectance was unchanged on 17,717 hectares (71\%). 6732 hectares 
(27.11\%) see an increase or decreased change in their reflectance but this change considered subtle as it fell below the threshold of 35\%. Beyond the threshold, change in reflectance was recorded on 489 hectares (1.97\%) with 15 hectares (mostly located on the shoreline) recording a decrease in reflectance while 321 hectares (1.29\%) had a significant increase in their reflectance. The last class can grossly be considered as the visible footprint of the $\mathrm{KDWH}$ while the change in reflectance noticed the long of the ocean shore might be the consequence of a change in the ocean/land transition triggered by the erection of the wharf. Considering the scattering of these parcels, a grouping of the changed areas was operated, and the area impacted by the KDWH was established at 714.05 hectares (Figure 7: The footprint of the Kribi Industrial Port Complex from the Landsat TM Imagery).

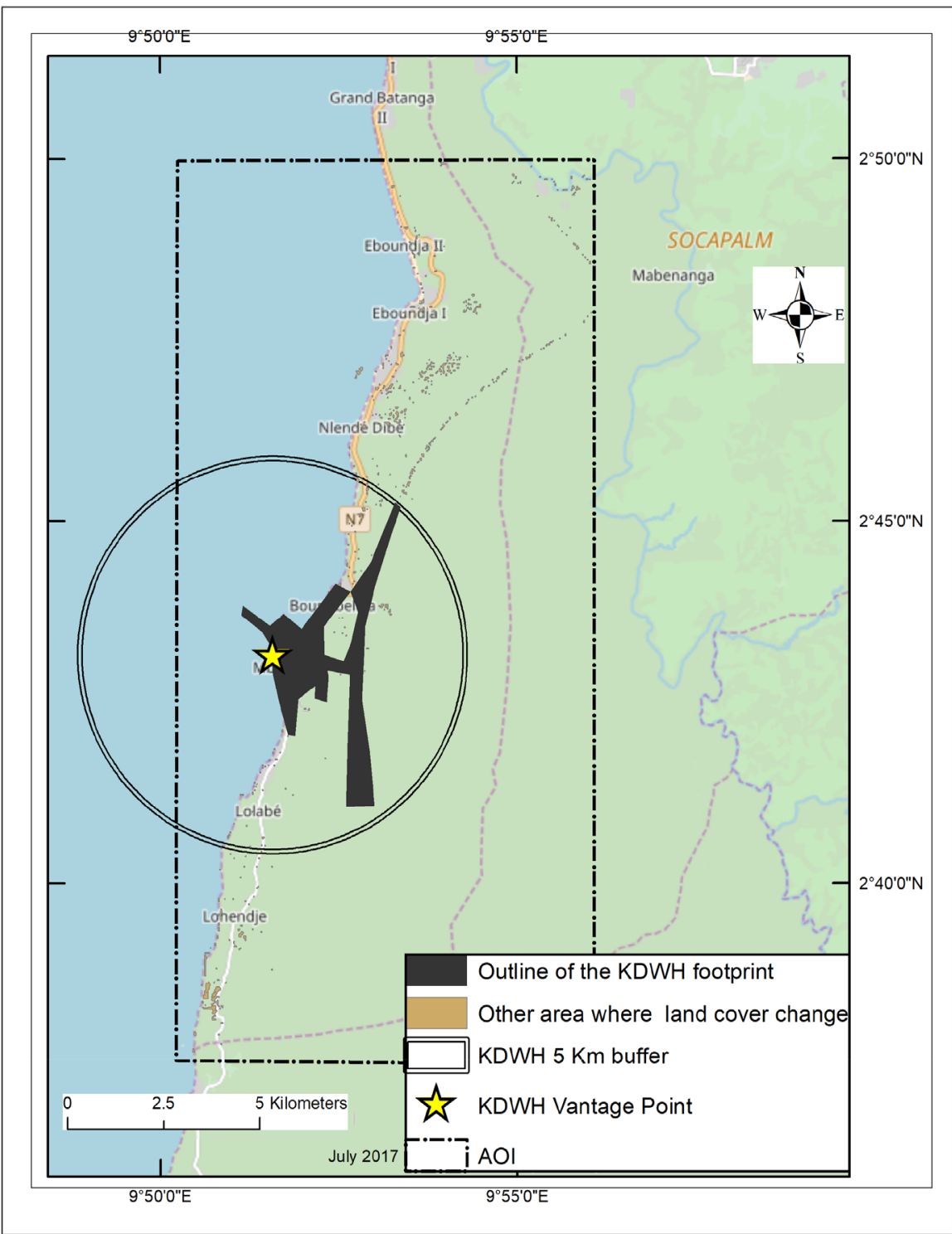

Figure 7. The footprint of the kribi industrial port complex from the landsat TM imagery. 
A spatial analysis of the distribution of the change show that the KDWH visible footprint is really in a radius of $2.5 \mathrm{~km}$ from the vantage point located at the southern pointe of the Wharf. Beyond that buffer, the only KDWH related damage is the $\approx 500 \mathrm{~m}$ width path, indicating the mark of the "Backbone". Its visible longitudinal scar is in the rim of $5 \mathrm{~km}$. Most of the area $5 \mathrm{~km}$ away from the KDWH was unchanged (Figure 8 KDWH Footprint by radius).

\section{Discussion and Limitations}

Despite its coarse-resolution, the synoptic view and spectral signatures capabilities of Landsat has proven to be a very efficient mean to assess the footprint of the KDWH at its present stage of development. A research project devoted to track subtle changes may had required higher resolution imagery, but the land cover changes induced by the KDWH are not. They are drastic. A higher resolution imagery $(1 \mathrm{~m})$ would of course have allowed a better discrimination of the land cover change. However, that is beyond the scope of this essay. In lieu of ground truth data, higher resolution imagery from Google Earth was used to certify the results.

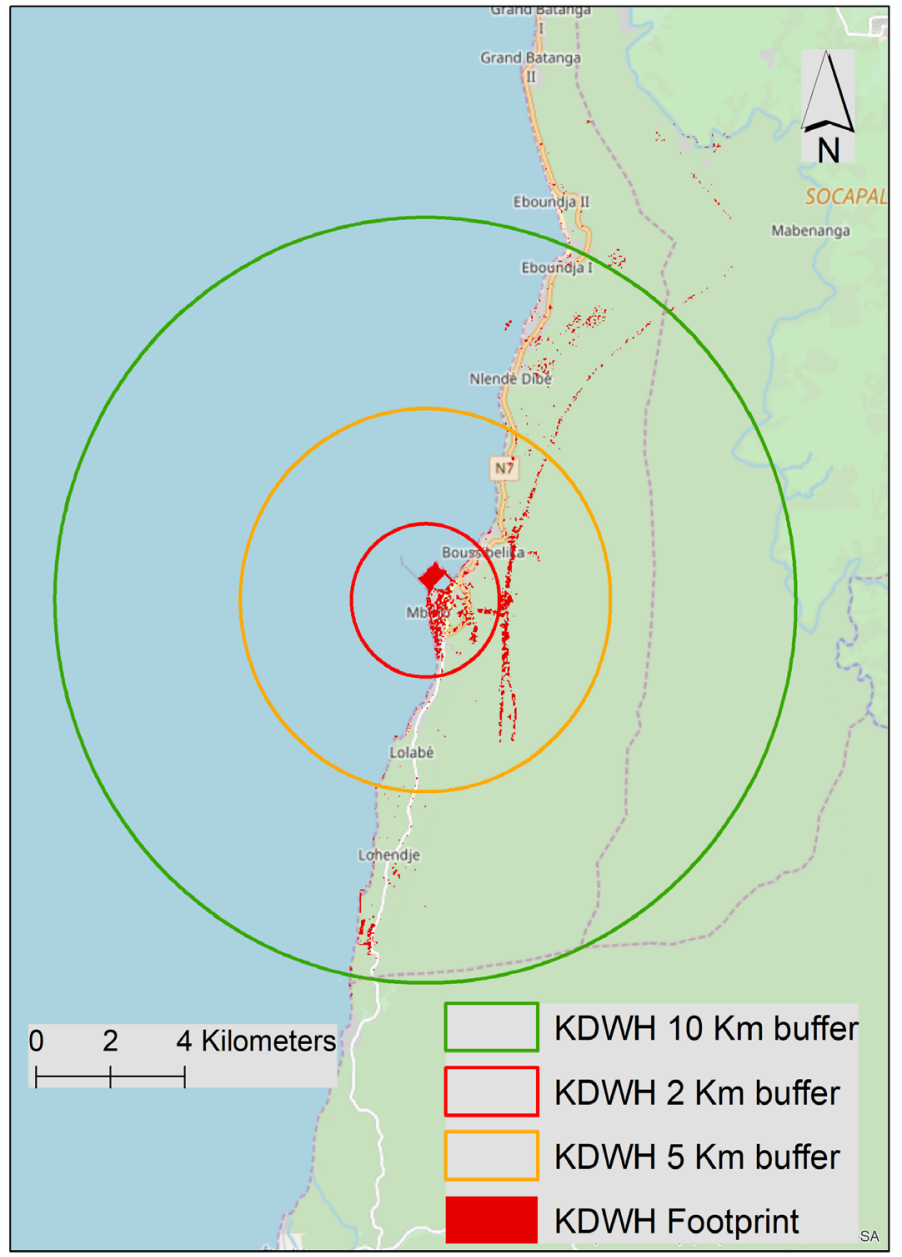

Figure 8 . KDWH Footprint by radius. 
From this prospective, the 26,000 hectares concession for the development of the KDWH do not has translated as far as a permit to destroy nor has it resulted yet into the huge destruction feared by the environmentalists. Unless the KDWH becomes a "white elephant", it is obvious that this forest is deemed to be destroyed at a rate difficult to predict. Research will continue surveys to monitor various impacts at every phase of this project (Figure 9: the footprint of the Kribi Industrial Port Complex (2015) in the Master Plan of the KDWH).

The environmental pitfalls of a development as gigantic as that of KDWH usually exceed any visible impact. The findings proposed in this paper do not address that, as it would have required a completely different methodology.

Beyond the predicted footprint of the KDWH, a spatial analysis of the land concessions and their dedication in this Southern coastal area of Cameroon reveals the real amplitude of the problem raised by the environmentalists. In fact,

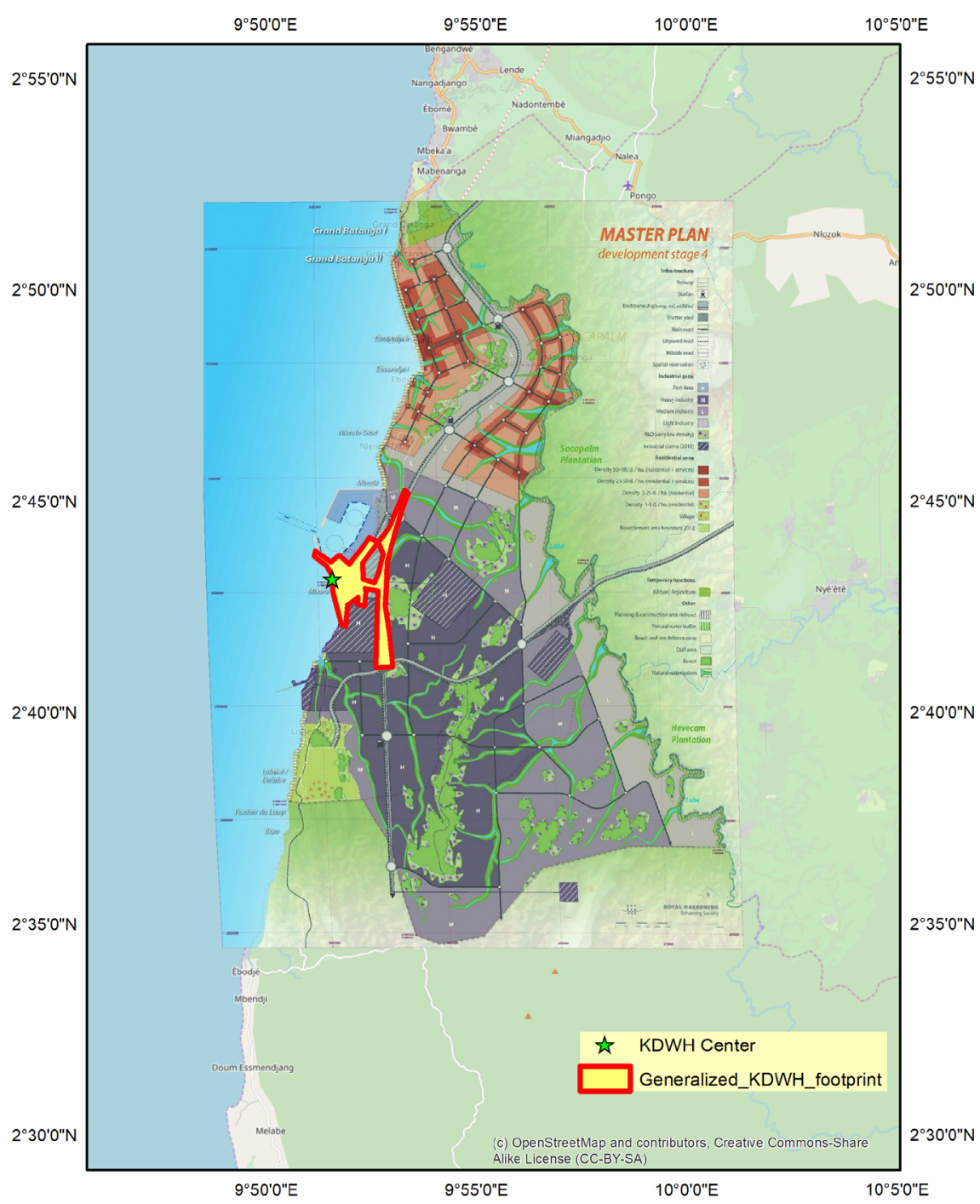

Figure 9. The footprint of the kribi industrial port complex (2015) in the master plan of the KDWH. 


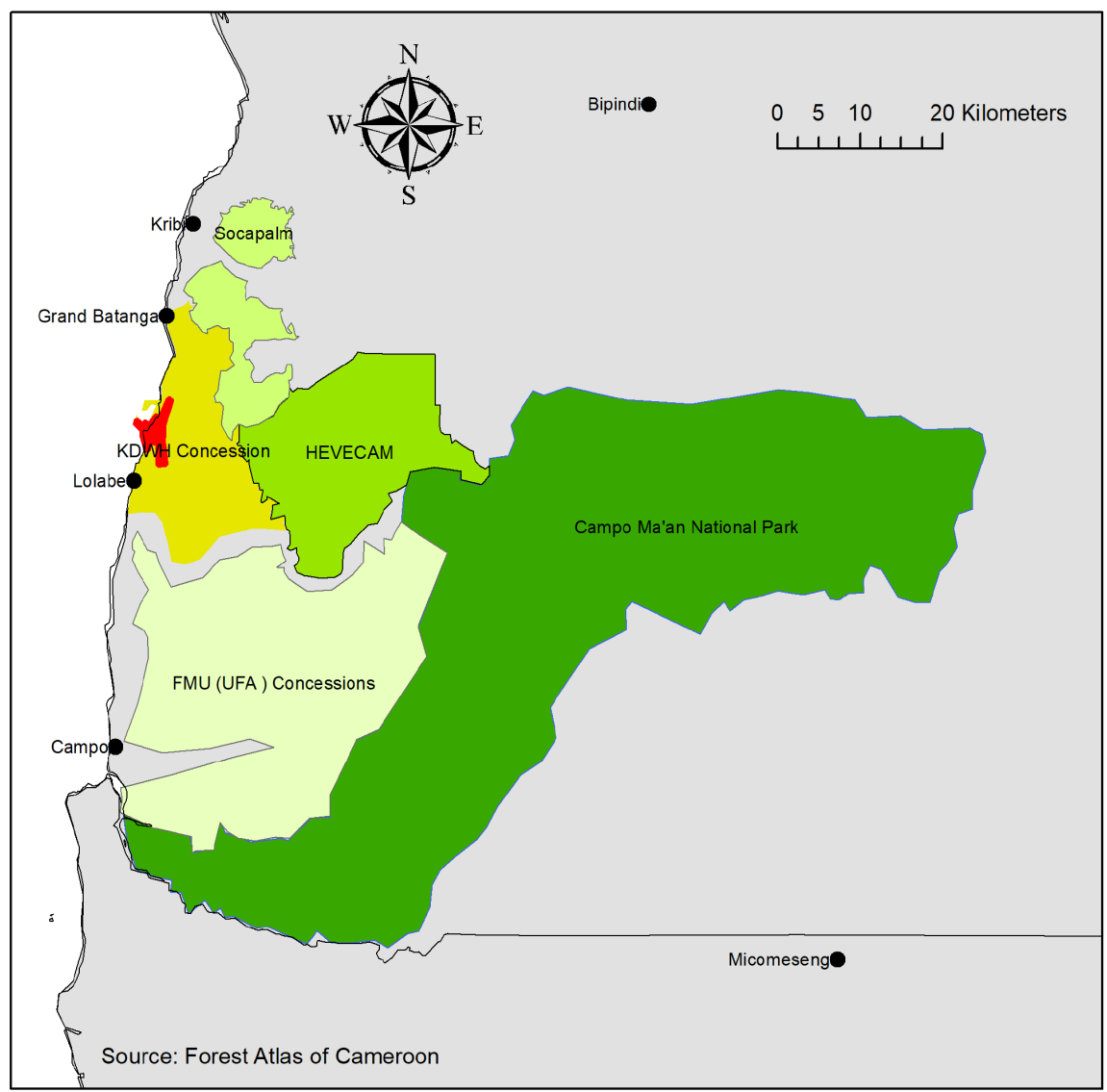

Figure 10. Land concessions and dedication in the KDWH area.

large areas of this Southern forest of Cameroon has been deforested to created industrial farms whose best known are Socaplam and Hevecam producing rubber and palm oil. HEVECAM has a concession of 70.000 ha for its plantations and Socaplam a concession of 23,000 ha. The remaining lands of the region are classified Forest Management Units (FMUs) such as the 09-025 with an area of 88,535 ha in whose logging companies are granted exploitation permits (Figure 10: land concessions and dedication in the KDWH area).

This land grabbing projects and concessions have resulted in the destruction of a rich biodiversity and consequently in jeopardizing the existence of local populations among whose the pygmies Bagyéli which rely on the forest for their food and their livelihoods.

\section{Conclusions}

The pixel-comparison of 2007/2015 Landsat 7 ETM images has permitted the detection and delineation of a major land-cover change in the Cameroon's coastal area were the Kribi Deep Water Harbor Project, is being developed. When conducting this study, the goal was not to detect the "natural" land cover change due to forest decline or regrow, but rather to seize the significant land cover change. Resorting to a higher threshold (35\%) has made that possible. 
From the analysis of the data obtained through image differencing, the visible footprint of the Kribi Deep Water Harbour Project is 714.05 hectares with the main portion constituted by the wharf and the $2 \mathrm{~km}$ radius area around. It should be mentioned that this result is not necessarily the measures of the current footprint, but those as of January 5th of 2015 (the date of the TM data acquisition).

This case study demonstrates how satellites imagery can be used to investigate a remote or difficult-to-access land condition effectively and efficiently. Similar efforts should be conducted across Cameroon whenever concerns of environmental stress are signaled to provide a better understanding of the magnitudes and patterns of changes taking place.

The Kribi Agro-industrial Port and urban Complex is a ground up non-colonial harbour endeavor. Despite the nepotism associated with its realization, it will likely redefine and redraw all the patterns of its service region and profoundly influence its spatial perimeter of influence. This study is a partial assessment of the environmental cost of this endeavor. Hopefully the KDWH does not duplicate Douala's cadastral and environmental problems [33].

Apparently blocked by a tough battle for its control [34], six years after its first stone was laid, three years after the completion of the quay, on March $2^{\text {nd }}, 2018$, with the docked of the first commercial ship the CMA CGM BIANCA flying the flag of Malta, and coming from Asia, the KDWH officially starts its operational activities. Since it is the most important project of the last fifty years in Cameroon, the KDWH requires a constant follow up at all levels for a better sustainability.

\section{Acknowledgements}

This research received no specific grant from any funding agency in the public, commercial, or not-for-profit sectors. We are grateful to the USGS for providing Landsat TM data for this research. This paper was improved following a helpful criticism of Professor Alexie Tcheuyap of the University of Toronto. Many thanks to Nels Degn for proofreading this work.

\section{References}

[1] Shannon, T. (2015) What's It Like to Have China Build You a Port? Ask Cameroon, The Diplomat, Washington DC.

[2] MINEPAT (2012) Port En Eau Profonde De Kribi Projet Majeur Des Grandes Réalisations. MINEPAT, Yaoundé.

[3] Kini, N. (2008) Limbe Seaport Controversy Rocks Parliament, 15 December. http://www.postnewsline.com/

[4] Santos, A. (2016) SWELA Queries Yaoundé over Limbé Deep Seaport Project. The Median Newspaper, Yaoundé.

[5] Harris, J., Neva, R. and Goodwin, R.N. (2003) Reconciling Growth and the Environment. Global Development and Environment Institute Working Paper No. 03-03, Tufts University, Medford. 
[6] Letouzey, R. (1985) Notice de la carte phytogéographie du Cameroun. Carte Internationale de la végétation Toulouse.

[7] Morin, S. and Kuété M. (1988-1989) Le Littoral Camerounais: problèmes morphologiques, Travaux du Laboratoire de Géographie Physique Appliquée $\mathrm{N}^{\circ} 11$, Institut de Géographie-Université de Bordeaux III, Talence.

[8] Giresse, P., Megope Foonde, J., Ngueutchoua, G., Aloisi, J., Kuété, M. and Monteillet, J. (1996) Carte sédimentologique du plateau continental du Cameroun et notice explicative 111, Orstom, Paris.

[9] Charlotte, F. (2013) Vision 2035 and the Kribi Deep Seaport: An Analysis of the Economic Impacts for Cameroon. Independent Study Project (ISP) Collection. Paper 1499. http://digitalcollections.sit.edu/isp_collection/1499

[10] Royal Haskoning (2012) Strategic and Masterplan of the Kribi Industrial Port Complex. Comité de Pilotage et de Suivi de la réalisation du complexe industrialo portuaire de Kribi.

[11] Singh, A. (1989) Digital Change Detection Techniques Using Remotely Sensed Data. International Journal of Remote Sensing, 10, 989-1003. https://doi.org/10.1080/01431168908903939

[12] Mertens, B. and Lambin, E.F. (2000) Land-Cover-Change Trajectories in Southern Cameroon. Annals of the Association of American Geographers, 90, 467-494. https://doi.org/10.1111/0004-5608.00205

[13] Verhegghen, A., Eva, H., Desclée, B. and Achard, F. (2016) Review and Combination of Recent Remote Sensing Based Products for Forest Cover Change Assessments in Cameroon. International Forestry Review, 18, No. 2.

[14] FAO (1979) Ecological Map of the Vegetation Cover of South Cameroon (Based on Landsat Images). FAO, Rome.

[15] UNEP (2003) Campo-Ma'an Forest. Environmental Change Hotspots. Division of Early Warning and Assessment (DEWA). United Nations Environment Programme (UNEP), Nairobi.

[16] FAO and ITTO (2011) The State of Forests in the Amazon Basin, Congo Basin and Southeast Asia. A Report Prepared for the Summit of the Three Rainforest Basins Brazzaville.

[17] Douard, P. and Hanson, C. (2014) New French Satellite Imagery to Help Forest Management in the Congo Basin.

[18] Siwe Ngamabou, R. (2006) Evaluating the Efficacy of Remote Sensing Techniques in Monitoring Forest Cover and Forest Cover Change in the Mount Cameroon Region. Doctorate Thesis, Department of Remote Sensing and Landscape Information Systems, Faculty of Forestry, and Environmental Sciences, Albert Ludwigs University, Freiburg im Breisgau.

[19] Njomo, D. (2008) Mapping Deforestation in the Congo Basin Forest using Multi-Temporal SPOT-VGT Imagery from 2000 to 2004.

[20] Rodriguez Montellano, A. and Armijo, E. (2011) Detecting Forest Degradation Patterns in Southeast Cameroon. Anais XV Simpósio Brasileiro de Sensoriamento Remoto, Curitiba, 30 de abril a 05 de maio de 2011, 1606.

[21] Mayaux, P., Pekel, J.-F., Desclee, B., Donnay, F., Lupi, A., Achard, F., Clerici, M., Bodart, C., Brink, A., Nasi, R. and Belward, A. (2013) State and Evolution of the African Rainforests between 1990 and 2010. Philosophical Transactions of the Royal Society B, 368, Article ID: 20120300. https://doi.org/10.1098/rstb.2012.0300

[22] Cannon, C.J. (2015) Satellite Images Show Deforestation on Fringes of UNESCO 
World Heritage Site in Cameroon.

https://news.mongabay.com/2015/05/satellite-images-show-deforestation-on-fringe s-of-unesco-world-heritage-site-in-cameroon

[23] Njeudeng Tenku, S., Xiao, X. and Dong, J. (2015) Depicting Forest Cover in Grand South of Cameroon: An Analysis Based on L-Band PALSAR 50-m Orthorectified Imagery. African Journal of Wood Science, and Forestry, 3, 198-210.

[24] Hirschmugl, M., Maier, A., Haas, S., Siwe, R., Schardt, M. and Amougou, J.A. (2015) REDD Pilot Project in Cameroon Monitoring Forest Cover Change with EO Data.

[25] Ndzeidze, S., Achia Mbih, R. and Bamboye, G. (2016) Using Remote Sensing to Detect Change in the Ndop Floodplain Wetlands of Cameroon. International Journal of Remote Sensing Applications, 6, 146-158.

[26] World Resource Institute (2011) The Interactive Forestry Atlas of Cameroon. http://www.wri.org/applications/maps/forestatlas/cmr/index.htm?maptheme=came $\underline{\text { roon\#v=atlas\&l=fr }}$

[27] Hansen, M.C., Potapov, P.V., Moore, R., Hancher, M., Turubanova, S.A., Tyukavina, A., Thau, D., Stehman, S.V., Goetz, S.J., Loveland, T.R., Kommareddy, A., Egorov, A., Chini, L., Justice, C.O. and Townshend, J.R. (2013) High-Resolution Global Maps of 21st-Century Forest Cover Change. Science, 342, 850-853. http://earthenginepartners.appspot.com/science-2013-global-forest http://www.globalforestwatch.org

[28] Wulder, M.A., et al. (2016) The Global Landsat Archive: Status, Consolidation, and Direction. Remote Sensing of Environment, 185, 271-283. https://doi.org/10.1016/j.rse.2015.11.032

[29] Hansen, M.C. and Loveland, T.R. (2012) A Review of Large Area Monitoring of Land Cover Change using Landsat Data. Remote Sensing of Environment, 122, 66-74. https://doi.org/10.1016/j.rse.2011.08.024

[30] Lu, D., Mausel, P., Brondizio, E. and Moran, E. (2003) Change Detection Techniques. International Journal of Remote Sensing, 25, 2365-2407.

[31] Coppin, P., Jonckheere, I., Nackaerts, K. and Muys, B. (2004) Digital Change Detection Methods in Ecosystem Monitoring: A Review. International Journal Remote Sensing, 25, 1565-1596. https://doi.org/10.1080/0143116031000101675

[32] Rogerson, P.A. (2002) Change Detection Thresholds for Remotely Sensed Images. Journal of Geographical Systems, 4, 85-97. https://doi.org/10.1007/s101090100076

[33] Tiafack, O., Ngouanet, C. and Ngwa Nebasina, E. (2014) Development Polarisation in Limbe and Kribi (Littoral Cameroon): Growth Challenges, Lessons from Douala, and Options. Current Urban Studies, 2, 361-379. https://doi.org/10.4236/cus.2014.24034

[34] Afrique, J. (2018) Bataille de loups à Etoudi autour du port de Kribi Jeune Afrique No. 2977 [Confidentiel]. 